\title{
Struggling for Rights: African Women and the "Sanspapiers" Movement in France
}

\author{
Cathie Lloyd
}

\begin{abstract}
This article considers the political impact of recent migration of women from West Africa to France in the context of draconian controls (the Pasqua Laws). It outlines the main characteristics of both the migration and the legislation, and analyses the principal features of the eighteen month dispute for the legalization of undocumented workers which has become known as the "lutte des sanspapiers."
\end{abstract}

\section{Précis}

Le présent article analyse l'impact politique de la migration récente des femmes d'Afrique de l'Ouest vers la France, dans le contexte de contrôle draconien actuel (lois Pasqua). On y décrit les principales caractéristiques de la migration et de la législation et on y analyse les principaux aspects des dixhuit mois de lutte pour la régulation des travailleurs sans pièce d'identité, connus désormais sous le nom de "lutte des sanspapiers".

The position of African migrant workers in France has changed radically over the past twenty years. In the postwar period, a largely male contract labour force was living in hostels largely segregated from the rest of the population. Today, while the recruitment of migrant labour has stopped, family reunification has meant that their expectations and needs in France have changed. Women are playing an important part in calling for the recognition of their rights as a community in France. At the same time, immigrants

Cathie Lloyd, Ph.D., is Director of the Centre for Cross Cultural Research on Women, Queen Elizabeth House, University of Oxford, Oxford, United Kingdom, and a member of the National Council of the Mouvement Contre le Racisme et Pour l'Amitié entre les Peuples (MRAP) in France. have lost many of their entitlements to welfare benefits and new categories of people without rights have been created.

There are some 140,000 West African immigrants (mainly from Mauritania, Mali and Senegal) living in France today. Since the 1970s, people have migrated to France while maintaining close ties with their homeland, sending back considerable sums in remittances to support local communities and development projects. The West African communities which have emerged exist on a contested cultural and political terrain. In order to remain in France, they have endured considerable hardships.

The participation of African women in struggles for rights in France has had a major impact in changing the way in which their community is perceived. However, this is not a straightforward process because their family relations and personal status may be defined in terms which are acceptable to the French establishment. Antiracist and solidarity associations also offer political opportunities through which women may make an impact even though they may not have formal political rights.

\section{Composition and Characteristics of West African Migration to France}

Government figures show some 140,000 people (including women and children) from Mali, Mauritania and Sénégal in France (La Croix, 10 September 1996; Le Monde, 24 September 1996). Compared with other immigrant populations in France, the West African presence is small. For instance, the combined figure for Algerian and Moroccans in 1992 was 869,854 and for French citizens from the DOM-TOM, $339,600 .^{1}$ By 1990 , women comprised 41 percent of migrants from sub-Saharan Africa, some 58 percent of whom are economically active (Institut national de statistiques 1992).

As a result of historical links formed from French colonial interest in Africa, there has been a small-scale West African presence in France for many years. Migration has long been an important source of revenue for villages in West Africa (Quiminal 1991). It is common for the community to save up for the fare to send young men to work in France. Reciprocity is central to this arrangement: in return for the chance to travel, the emigrant is expected to send back remittances to assist the whole community. With such money, towns and villages in West Africa can construct wells and water supplies and build dispensaries and other public buildings. It is estimated that at current prices, one man working in Paris can send enough home to West Africa to sustain fifty people (Le Monde, 18 August 1996; Libération, 25 September 1996).

The single men who went to work in France in the 1960 s and 1970 s constructed networks based on family, village or ties of friendship which helped to mitigate the austerity and isolation of their lives in hostels. They only saw their wives and children when they returned home for holidays, which was limited because of the high cost of the return fare to France. Since the French government restricted immigration from the early 1970s, it became increasingly difficult for new migrants to replace those who had already spent time in France. The legal right to stay in France had been bound up to a requirement to have "adequate" housing since the Marcellin-Fontanet circulars (1972) which required employers to provide certificates of housing and employment, thus placing workers further in the power of their employers. Similar 
regulations were used later as criteria for family reunification.

Immigration controls acted as a "pull factor" in the mid 1970s, encouraging families to come while they could. There was the additional inducement of rearing a family in France with the benefits of a French education and employment opportunities, and until 1993, children born in France could automatically become French citizens under the nationality laws (Libération, 10 August 1996). As families arrived, there was greater pressure to obtain decent housing, although according to the 1990 census, 85 percent of West Africans were still living in hostels.

Family reunification meant that wages were stretched still further to maintain families in France while also meeting commitments in Africa. On arrival in France, many women were more dependant on their husbands than they had been at home. West African men had mainly been employed on short-term contracts in low paid, insecure manual occupations, cleaning in public transport and streets, or perform manual tasks in factories. The tertiary sector has become increasingly important, and many women who work are employed in hotel and catering jobs. The men tended to take charge of the household economy because of their command of the French language. However, women have rapidly set up trading and organizations for economic solidarity through savings groups (tontines), which were also used to engender friendship and community networks (Institut Panos 1994; Nicollet 1994).

\section{Earlier Struggles for Decent Living Conditions}

In the past, African migrant communities had attempted to make their lives more bearable in France in different ways. They established structures within the hostels by which they could help one another with necessary purchases and to channel remittances back to their villages (Jones 1991; Quiminal 1991). When, in 1975, the French authorities increased hostel rents, many hostels declared a rent strike which lasted for several years. Although rents were the precipitating factor, the dispute was also about ending the degrading conditions of life in the hostels, and for the recognition of immigrant representation in their daily management. The dispute became embroiled in the internal conflicts of the French left, but it did mark an important early stage in the recognition of the African migrant community in France (Freeman 1979; Miller 1981; Wihtol de Wenden 1988). In many ways, it paved the way for family reunification not least by establishing community structures which could relate to French political structures.

As family reunification was taking place, there have, however, been serious material difficulties which have given rise to a number of disputes about housing. One action in particular, in which a tent village was set up at Vincennes (on the outskirts of Paris), was initiated by a group of women who could no longer bear the sordid conditions in which they were housed. The majority of people in the Vincennes protest were women and children and they made a major symbolic impact by bringing their daily lives into the public arena. The visibility of women and children began to challenge media stereotypes of the African as male migrant workers (Le Nouvel Observateur 1992). However, this potential source of inspiration for humanitarian support was not fully exploited by those in charge of the negotiations with French housing authorities, and the tent city was disbanded as winter approached.

\section{The Sanspapiers}

In 1993, legislative elections returned a right-wing National Assembly to government, and a second period of cohabitation began with socialist President Mitterrand. In 1995, the rightward shift was confirmed by the election of the neo-gaullist Jacques Chirac as President. The right had been seriously divided over the attitude to take towards the extreme-right Front National. In 1993, the Minister of the
Interior, Charles Pasqua enacted a series of restrictive measures on immigration which were complemented by rigorous identity controls, and a reform of the nationality code. This meant that young people born in France of foreign parents were no longer automatically French citizens (Groupe d'information et de solidarité avec les travailleurs 1995; Libération, 30 April 1993). These measures enormously increased the amount of law, circulars and decrees which regulated the lives of foreigners in France. They instituted a regime of suspicion, enabling mayors to make an investigation before permitting marriage between a French citizen and a foreigner (Libération, 8 June 1993). The laws created new categories of people who were not entitled to full residence permits and all the attached social rights, but who could not be deported because they were the parents of French children. Ambiguity and arbitrary administrative measures gave rise to many cases where people who had been living and working legally in France for many years found themselves denied a legal status and at risk of deportation. Their position was aggravated by a virulent media debate against "clandestins," who were spoken of in the same breath as crime, drug-dealing and terrorism in broad political discourse.

This is the context of the sanspapiers protest which began in March 1996. Though not directly a housing issue, it arose in the context of an escalation of housing disputes organized by the Droit au Logement (DAL), a housing rights campaign which specializes in direct action, occupying empty buildings and using publicity to make it difficult to evict them. Their action at the rue du Dragon, in the Saint Germaine area of Paris during 1995, held the media headlines with its imaginative and theatrical campaigning, and linked the campaigns for the rights of immigrants with those of all homeless people (Droits Devant! 1995).

On March 18, 1996, a group of 300 West African families occupied the Church of Saint Ambroise (Paris XI) as 
a way of claiming their rights to residence papers. They were rapidly evicted from the church at the request of the local priest. About forty Malien men were arrested, some of whom were deported. Over the next few months, the families lived in a succession of local buildings, owned by the church, trade unions and later the radical theatre La Tempete at the Cartoucherie in Vincennes. They used this nomadic existence to broaden their basis of support among radical media workers and trade unionists. At the beginning of April, the protesters were joined by a "college of mediators" comprised of eminent French "personalities" including lawyers, an ex-ambassador (Stéphane Hessel) and academics (such as Jacqueline CostaLascoux, Pierre Vidal-Naquet and Laurent Schwartz). They acted as a bridge between the sanspapiers and the government to persuade the latter to suspend deportations, and to negotiate a humane outcome. They insisted that the sanspapiers were not clandestine immigrants because they had not entered France illegally, but had lost entitlement to papers because of changes in the law. About a month after the beginning of the dispute, eight people began a hunger-strike. At the same time, the mediators assisted the protesters in collating files with which they could make the case for regularization, and the government began to study them.

During the summer, the movement grew, with new groups of sanspapiers developing in different parts of France. At the beginning of the holiday period, when political France usually closes down, the main body of protesters took refuge in the church of SaintBernard in the 18th arrondissement of Paris. This was considered to be a safe place: the local parish priest supported the protesters, the 18th arrondissement is an area where many immigrants live, and there are local associations which could be expected to help. Trade unionists and church congregations continued to organize solidarity vigils and material support while the government remained intransigent, refus- ing to consider any change in the criteria for regularization. After a meeting between the Prime Ministers office and the mediators in August, the church of Saint Bernard was unexpectedly raided at dawn on the 12th of August by the CRS riot police (Compagnie régionale de securité), and hunger strikers, children and mothers were evicted.

If the government had hoped that the raid could have passed unnoticed during the summer holidays, they were mistaken. There was a media furor, and film stars such as Emmanuelle Béart were photographed being dragged out of the church chained to members of the African families. Public opinion responded to the breach of the sanctity of the church, the legitimation of the protesters by media personalities, but first and foremost, to the sight of mothers and children being terrorized by the intimidating and unpopular CRS.

Madjiguène Cissé, one of the spokespeople for the protesters, has described how the women kept the protest going despite the men's discouragement. Men were ready to disperse the protest on several occasions. Cissé $(1996,12)$ explained how at first the men did not allow women to attend the meetings to discuss the conduct of the protest, and how, through their own women's organization, they developed the resources to insist on such participation. The West African women played a prominent role in giving interviews to the press about how they came to France with their families, and appealing to human sympathy and solidarity by revealing the impoverished conditions in which they were obliged to live. Many of the women interviewed had been left alone in France because theirhusbands had been deported, and they now faced destitution and isolation, unable to speak the French language fluently. The resources of educated women such as Madjiguène Cissé, who has a masters degree in German, has proved crucial (Cissé 1997). Cissé revealed herself to be a talented orator, who, in defending herself and her colleagues against deportation, reminded the tribunal of the historical links between France and Senegal, the role of the Tirailleurs Sénégalais in defending France during two world wars, and the long history of labour migration. She referred to the role of women in the railway workers strike of 1947 , and more recently, in protesting against the conduct of elections in 1988 (Cissé 1996; Sembene 1976). When asked why she refused to give her name in court, she replied that she had forgotten that she had a name because she had not been treated with the respect due to a human being.

There were many positive images of women in the press: West African women were portrayed as suckling babies, wearing colourful clothes, and dancing at the front of demonstrations. They were depicted as not necessarily confined to the household, but often shown as leading street demonstrations and rallies (Bataille 1996). Above all, women as mothers challenged the criminalized stereotype of "clandestin." They could be seen as disrupting the "normal" public/domestic division which underscored gender relations in political life to the detriment of women (Rosaldo and Camphere 1974). Public opinion was frequently reminded that many of the children in the sanspapiers protest were legally entitled to French citizenship when they reached the age of sixteen. Protective attitudes towards children and respect for family life could come into play. This is often successfully used in French immigration hearings to assert the right to family life under article 16 of the United Nations Universal Declaration of Human Rights (Prencipe 1994).

This way of using the family has given rise to some disquiet among the sanspapiers and their supporters who are aware of the tendency for the family to be defined as the Western-style nuclear family. If immigrant families are given a privileged status, there was a danger that other immigrants would be seen as less worthy of support. So, in recent statements, there have been attempts to correct the emphasis by 
stressing the rights of single people (usually meaning men), to a stable personal life (Plein Droit 1996, 1-2).

The sanspapiers action took place at a moment when support organizations were well prepared to act because they seemed to embody all the anticipated problems with the Pasqua law of 1993. It was therefore possible to translate their protest into mutually acceptable political demands. The mediators helped to take the case of the sanspapiers into formal political and legal channels by attempting to negotiate with the government on the basis of class actions, rather than individual cases, which might have been divisive. The issue was expanded in interaction with trade unions by linking the insecurity of the sanspapiers and their families to broader social insecurity, which was threatening many people because of the Chirac government's plans for privatization in order to meet the Maastricht EMU convergence criteria. To great applause, the sanspapiers led the march of 100,000 public sector trade unionists against privatization in October, 1996. Their links with associations for social justice, especially in Senegal and Mali, were exploited during the visit of the Minister for $\mathrm{Co}$ operation (Development) to those countries in September, enabling French newspapers to publish detailed information about the contribution which migrants made to the development of their countries of origin, and to express concern that the image of France in the world was not enhanced by the spectacle of women and children being evicted from a church.

Since the election of a new socialist government in June 1997, a new circular has been issued instructing officials to re-examine the entitlements of "irregular foreigners" (Ministère de l'Intérieur 1997). While legislation is promised for the autumn, at the time of writing (July 1997), many solidarity organizations are overwhelmed by applications from people hoping for regularization. Their reaction is to discourage over-optimism, and to attempt to negotiate a difficult line between helping individuals without encouraging divisions. In the present circumstances, it will be difficult to sustain a united campaign.

The sanspapiers and their supporters aimed to change the terms of the debate about immigration in France. This meant going beyond the political consensus in regard to the idea of "closed frontiers," to argue for a more realistic approach which accepted that immigration will continue to take place. The sanspapiers dispute threw new light on how ordinary people can find themselves "without papers" even though they had entered France legally, they had, nonetheless, fallen into the category of "illegal" because of the administrative complexity arising from the Pasqua laws. The dispute has succeeded in voicing the personal experiences of women and men who have fallen foul of immigration controls. The sanspapiers website (in English, French and Wolof) exemplifies this very broad approach to political struggle. ${ }^{2}$ The protest has used this and other media to inspire similar actions on behalf of undocumented workers in Europe (specific examples would include the Netherlands, Spain and the United Kingdom) and in North America.

\section{Notes}

1. The French Overseas Dominions and Territories are mainly in the Caribbean. Their inhabitants are full French citizens.

2. The website is at: http://bak.net/pajol/fr.

\section{References}

Bataille, C. 1996. "Pas de printemps pour les sanspapiers: Une volonté à toute épreuve". Cahiers de Féminisme, no. 77 Ete.

Cissé, M. 1996. "Sanspapiers: les premiers enseignements". Politique: La revue (October/ December).

—. 1997. The Sans-Papiers: The New Movement of Asylum Seekers and Immigrants Without Papers in France-A Woman Draws the First Lessons. London: Crossroads.

Costa-Lascoux, J. 1996. "Pour une autre politique de l'immigration". Différences, no 179 (November): 2-4.
Droits Devant! 1995. "Effets Pasqua: Les Faits". No 5, 9 (June).

Freeman, G. 1979. Immigrant Labour and Racial Conflict in Industrial Societies. Princeton: Princeton University Press.

Ministère de l'Intérieur. 1997. Circulaire Nor/int/D/97/000104/C,24June.Paris.

Groupe d'information et de solidarité avec les travailleurs (GISTI). 1995. Entrée et séjour des Etrangers. La Nouvelle Loi Pasqua. Paris: GISTI.

Institut national de statistiques (INSEE). 1992. Rencensement de la population de 1990: nationalités, résultats du sondage au quart. Patris: INSEE.

Institut Panos. 1994. Quand les immigrés du Sahel construisent leur pays. Paris: Ed Institut Panos-L'Harmattan.

Jones, P. 1991. "Race, Discourse and Power in Institutional Housing: The Case of Immigrant Worker Hostels in Lyon." In Race, Discourse and Power in France, edited by M. Silverman, 55-70. Aldershot: Avebury.

La Croix. 10 September 1996.

Le Monde. 18 August 1996.

—. 24 September 1996.

Le Nouvel Observateur. 1992. “1,600 Noirs à la recerche d'un toit". 16-22 July, 74-75.

Libération. 30 April 1993.

—. 8 June 1993.

- 10 August 1996.

-. 25 September 1996.

Miller, M. 1981. Foreign Workers in Western Europe: An Emerging Political Force. New York: Praeger.

Nicollet, A. 1994. "Les enjeux féminins d'une migration Africaine". Migrations Société VI, no. 35 (Sept.-Oct.).

Plein Droit. 1996. No. 33 (November): 1-2.

Prencipe, L. 1994. "Famille-Migrations-Europe: Quelles relations possibles?" Migrations Société VI, no. 35 (Sept.-Oct.): 27-42.

Quiminal, C. 1991. Gens d'ici, gens d'ailleurs. Paris: Christian Bourgeois.

Rosaldo, M., and L. Camphere, eds. 1974. Women, Culture and Society. Stanford: University of Stanford Press.

Sembene, O. 1976. God's Bits of Wood. London: Heineman African Writers Series.

Wihtol de Wenden, C. 1988. Les Immigrés et la Politique. Paris: PFNSP. $\square$ 